British Association for the Advancement of Science A Scientific Survey of Blackpool and District. Prepared for the Blackpool Meeting, 1936, by various Authors. Edited by Arthur Grime. Pp. 152+3 plates. (London: British Association for the Advancement of Science, 1936.) n.p.

The well-known British Association handbooks prepared annually for each centre visited have now for some years been issued in a uniform format, and if the appearance of the pamphlets is less impressive than the bound volumes of former days, the contents shows a marked improvement, and leaves little to be desired.

The handbook for the Blackpool meeting begins with an exhaustive survey of all aspects of the Fylde, illustrated by several useful maps. This includes chapters on the historical geography and the place names. A section of Lancashire sea fisheries follows. Then comes an account of the growth of Blackpool itself, from which we learn that there was a Blackpool of a few cottages so far back as the seventeenth century, and that the seaside resort began to be known in the eighteenth century. It was not, however, until the second half of the nineteenth century that the great growth set in. A full account is given of this growth and of the varied municipal activities of the borough. The coast defence works are also fully explained. Lastly come chapters on the geology and natural history of the Lake District, added no doubt in view of the excursions to that part of England. The book maintains the high standard of recent volumes in the series and reffects credit on its numerous contributors.

\section{A Method of Illustration for Zoological Papers}

By H. Graham Cannon. Pp. $\mathrm{x}+36$. (London : Association of British Zoologists, 1936.) To Members, 2s. $6 d$. ; to non-Members, $3 s$.

Azтнолен so much illustration of scientific papers is now performed by photographic methods there are still many cases where the process fails, such as com. plicated anatomical subjects, or those that present difficult problems of lighting or where a semi-diagrammatic treatment is called for. These require a selection and emphasis of parts which can still only be done by hand. The comparative ease and accuracy of the photographic process has done much to kill many of the older forms of art. Lithography, which in the past has produced such magnificent work, is almost as much a thing of the past as the woodcuts of Bewick. But as handwork is not, and never can be, entirely superseded, the student and advanced worker will be glad of any help that will get him over the technical difficulties in making his drawings. Everyone should at least try to produce his own illustrations with his own hand.

Prof. Graham Cannon has written a small booklet, published by the Association of British Zoologists, in which he claims that "any zoologist as long as he can draw a reasonably straight line . . . can turn out drawings that are really convincing". The method advocated appears sound and the illustrations of the method also appear convincing.
Bibliography of Soil Science, Fertilizers and General Agronomy, 1931-I934

Pp. xxxi +473. (Harpenden: Imperial Bureau of Soil Science, 1935.) 25s. net.

IN 1929-1930, eight Imperial agricultural bureaux were set up to act as clearing houses of information on different aspects of agricultural research and practice for the use of research and advisory officers in the Colonies and Dominions. One of their functions has been to issue abstracts of all the important papers and reports published in every country that bear on their respective subjects. The book under review is an index of all the papers abstracted by the Imperial Bureau of Soil Science, one of these eight bureaux, during the four years it has been issuing abstracts. It covers all the agricultural aspects of the work done in soil science, and in soil and crop management, but is only concerned with plant breeding, plant diseases or animal husbandry in so far as they depend on the soil or its management.

The book is an index of published papers. It gives the author, the title of the paper in English, the journal and the year in which it was published, but it does not give abstracts of the papers. The entries are grouped according to subject, or to the country to which they refer, and the subjects and countries are printed in the order of the numbers which they are given in the universal decimal classification. There is a detailed subject index running to fifty-five pages to enable one to find the number allotted to every subject, and it appears to be excellent.

There are three indexes, the subject index already noted, an index of all the journals quoted, and an author index. A minor criticism can be levelled at the author index in that it only gives one transliteration of a name from a non-Roman to the Roman alphabet, even though the author himself uses several. E. W. R.

\section{Principles of Electric and Magnetic Measurements}

Part 1: Electricity, by P. Vigoureux; Part 2: Magnetism, by C. E. Webb. (The Student's Physics, Vol. 7.) Pp. xi+392. (London, Glasgow and Bombay : Blackie and Son, Ltd., 1936.) 20s. net.

THIs text has the advantage that the authors are at the fountain of standardization in electrical science at the National Physical Laboratory and their modern treatment of their respective subjects is thereby enhanced. They start off by carefully de. fining their units and one is pleased to note the adoption of the new scheme of units based on the kilogram-metre-second system which is to unify the theoretical electro-magnetic and practical electrical units throughout the world in a few years time.

The present interdependence of physics and electrical technology is illustrated by the space given to thermionic devices, quartz crystals, the precision measurement of frequency, and even the linear timebase is mentioned, although, for some reason, the latter is not included in the index. The text is made suitable for students and research workers, but the field is becoming so vast that one must be sympathetic. L. E. C. H. 